\title{
Iron status of suckling rats as influenced by maternal diet during gestation and lactation
}

\author{
BY BARBARA A. KOCHANOWSKI AND ADRIA R. SHERMAN \\ Department of Foods and Nutrition and Division of Nutritional Sciences, \\ University of Illinois, Urbana, Illinois 61801, USA
}

(Received 25 January 1982 - Accepted 24 June 1982)

1. Two experiments are reported. In Expt 1, pregnant Sprague-Dawley rats (200-220 g) were given purified diets containing $35,75,150$ or $300 \mathrm{mg} \mathrm{Fe} / \mathrm{kg}$ throughout gestation and lactation. In Expt 2, the levels of Fe given were 250 and $300 \mathrm{mg} / \mathrm{kg}$ diet.

2. Litters were standardized at birth to contain seven pups. On day 20 of lactation blood, milk, spleen and liver were collected for $\mathrm{Fe}$ analysis.

3. A dietary $\mathrm{Fe}$ concentration of $35 \mathrm{mg} / \mathrm{kg}$ maintained maximum weight gain, food intake, liver and spleen weight, haemoglobin concentration and packed cell volume in the growing maternal rat through $20 \mathrm{~d}$ of lactation. Dam liver and spleen Fe concentrations were maximized between 75 and $250 \mathrm{mg} \mathrm{Fe} / \mathrm{kg}$ diet.

4. Pups (20-d-old) nursed by dams given $35 \mathrm{mg} \mathrm{Fe} / \mathrm{kg}$ tended to have lower body and organ weights compared to other groups. Liver and spleen Fe concentrations increased with increasing maternal dietary Fe and were significantly increased between 150 and $250 \mathrm{mg} \mathrm{Fe} / \mathrm{kg}$.

The Subcommittee on Animal Nutrition of the US National Research Council (National Research Council, 1978) has suggested that the rat's dietary iron requirement for growth and adulthood is $35 \mathrm{mg} / \mathrm{kg}$. This requirement was derived from experiments performed by McCall et al. (1962) who found that between 34 and $50 \mathrm{mg} \mathrm{Fe} / \mathrm{kg}$ diet permitted the maximal rate of weight gain and maintained haemoglobin concentration during the growth phase.

It is likely that the growing rat requires supplemental dietary Fe during reproduction. McCall et al. (1962) assessed the nutritional adequacy of a semi-synthetic diet containing $240 \mathrm{mg} \mathrm{Fe} / \mathrm{kg}$ for reproduction. Using the criteria of haemoglobin concentration and weight gain, they concluded that $240 \mathrm{mg} \mathrm{Fe} / \mathrm{kg}$ diet supported growth and reproduction through three generations. There have been two other studies reported in which the need for additional dietary Fe during pregnancy has been examined. Ahlstrom \& Jantti (1969) found that while maximal haemoglobin production in pregnant rats was maintained by a dietary Fe level of $28 \mathrm{mg} / \mathrm{kg}$, production of maximal Fe stores in offspring at birth required $58 \mathrm{mg}$ $\mathrm{Fe} / \mathrm{kg}$ diet. More recently, Lin \& Kirksey (1976) reported that growing, pregnant rats needed between 50 and $250 \mathrm{mg} \mathrm{Fe} / \mathrm{kg}$ diet to attain maximal foetal liver Fe stores, even though between 10 and $50 \mathrm{mg} \mathrm{Fe} / \mathrm{kg}$ diet maintained maximal haemoglobin production. Neither of these studies, however, extended through any part of lactation, when rat pups are dependent on maternal milk as their only source of nutrition.

Based on available information, it appears that the amount of dietary Fe determined to be optimal for the reproducing rat depends on the criteria used to evaluate Fe status and on whether Fe status is assessed in dams or pups or both. A search of the literature failed to reveal any additional information on the optimal dietary Fe level for the rat during both pregnancy and lactation. The purpose of the present study was to examine the effects of various dietary Fe levels fed throughout pregnancy and lactation on the Fe status of dams and pups at the end of the suckling period. The criteria used to evaluate Fe status included haematological values as well as Fe stores of liver and spleen. Our results suggest that feeding dams $75-250 \mathrm{mg} \mathrm{Fe} / \mathrm{kg}$ diet throughout gestation and lactation results in optimal 
$\mathrm{Fe}$ stores in weanling pups, although lower dietary Fe levels support weight gain and maximum haemoglobin production.

\section{EX PERIMEN TAL}

\section{General animal care}

Nulliparous, Sprague-Dawley, female rats (Harlan Industries, Indiana), weighing $180-200 \mathrm{~g}$, were housed in individual, suspended, mesh stainless-steel cages in a room with controlled temperature $\left(21-22^{\circ}\right)$ and a $12 \mathrm{~h}$ light-dark cycle. Rats were mated when their weight reached 200-220 g. Pregnancy was confirmed by the presence of sperm in vaginal smears. Pregnant rats were randomly assigned to an experimental group and given the appropriate diet and demineralized water ad lib. throughout gestation and lactation. Body-weights and food intakes were recorded weekly. Before delivery of the young, dams were placed in solid-bottom maternity cages with Fe-free bedding. Food dishes were positioned in the cages such that only dams had access to food and maternal milk was the only nourishment for the pups.

\section{Diets}

The composition of the basal diet used in Expts 1 and 2 is shown in Table 1. The basal diet contained $35 \mathrm{mg} \mathrm{Fe} / \mathrm{kg}$ and additional dietary Fe levels were obtained by supplementing the basal diet with $\mathrm{FeSO}_{4} \cdot 7 \mathrm{H}_{2} \mathrm{O}$. All diets were supplemented with cupric carbonate at the expense of sucrose to obtain a copper concentration of approximately $11 \mathrm{mg} / \mathrm{kg}$ diet, since Cerklewski (1979) has suggested that $9 \mathrm{mg} \mathrm{Cu} / \mathrm{kg}$ diet is necessary for optimal $\mathrm{Cu}$ status in the dam during reproduction and in the offspring at weaning. Dietary $\mathrm{Fe}$ and $\mathrm{Cu}$ concentrations were determined by atomic absorption spectrophotometry. All materials used for diet preparation were acid-washed glass, stainless steel or plastic to avoid $\mathrm{Fe}$ contamination.

\section{Expt 1}

Four groups of pregnant rats (eight to nine rats/group) were given diets containing one of four Fe levels, 35, 75, 150 or $300 \mathrm{mg} / \mathrm{kg}$ diet, throughout gestation and lactation. Litters were adjusted on day 1 to contain seven pups. The remaining pups were killed with chloroform, their stomachs drained of any milk, and the carcasses frozen for total body Fe analysis. On day 20 of lactation dams and their litters were separated for $2-3 \mathrm{~h}$ before milk collection. Dams were anaesthetized with sodium pentobarbital $(60 \mathrm{mg} / \mathrm{ml} ; 0.4 \mathrm{ml} / \mathrm{kg}$ body-weight) and injected intraperitoneally with oxytocin (10 USP units $/ \mathrm{ml} ; 0.25 \mathrm{ml} / \mathrm{kg}$ body-weight). Samples $(2-4 \mathrm{ml})$ of milk were then collected from each dam by gently palpating the mammary gland.

Pups were killed without previous fasting. One pup from each litter was killed with chloroform and the intact carcass frozen for total body $\mathrm{Fe}$ analysis. The remaining pups were anaesthetized with chloroform and blood was collected from pups and dams by cardiac puncture. Liver and spleen were removed from each animal, weighed and frozen at $-20^{\circ}$. All equipment used in killing the animals was plastic, stainless steel, or acid-washed glassware to minimize Fe contamination.

\section{Expt 2}

Pregnant rats were randomly assigned to one of two experimental groups of ten animals each. Diets contained either 250 or $300 \mathrm{mg} \mathrm{Fe} / \mathrm{kg}$. Animal treatments and procedures were performed as in Expt 1. 
Table 1. Composition of basal diet $(\mathrm{g} / \mathrm{kg})$

\begin{tabular}{lr}
\hline & \\
Casein* & 220 \\
Sucrose & 300 \\
Maize starch & 315 \\
Maize oil $\dagger$ & 100 \\
Cellulose $\ddagger$ & 20 \\
Vitamin mix $\|$ & 10 \\
Iron-free AIN-76 mineral mix§ & 35 \\
\hline
\end{tabular}

* Vitamin-free test casein; Teklad, Madison, Wisconsin.

$\uparrow$ Mrs Tucker's pure maize oil; Anderson Clayton Foods, Dallas, Texas.

\$ Alphacel; ICN Nutritional Biochemical Co., Cleveland, Ohio.

\| No. 40060; Teklad, Madison, Wisconsin. Composition of vitamin mix ( $\mathrm{g} / \mathrm{kg}$ vitamin mix): $\rho$-Aminobenzoic acid 11.0132 , ascorbic acid (coated; $97.5 \%$ ) 101.6604, biotin 0.0441 , cyanocobalamin 2.9736 ; calcium pantothenate 6.6079, choline dihydrogen citrate $349 \cdot 6916$, folic acid $0 \cdot 1982$, myoinositol $11 \cdot 0132$, menadione $4 \cdot 9559$, niacin $9 \cdot 9119$, pyridoxine hydrochloride $2 \cdot 2026$, riboflavin $2 \cdot 2026$, thiamin hydrochloride $2 \cdot 2026$, dry retinyl palmitate $3 \cdot 9648$, dry cholecalciferol 0.4405 , dry $\alpha$-tocopheryl acetate $24 \cdot 2291$, maize starch 466.6878 .

$\S$ Teklad, Madison, Wisconsin. Composition of mineral mix ( $\mathrm{g} / \mathrm{kg}$ mineral mix): $\mathrm{CaH}_{2} \mathrm{PO}_{4} 500 \cdot 0, \mathrm{NaCl} 74 \cdot 0$, potassium citrate monohydrate $220 \cdot 0, \mathrm{~K}_{2} \mathrm{SO}_{4} 52 \cdot 0, \mathrm{Mg0} 24 \cdot 0, \mathrm{FeSO}_{4} .7 \mathrm{H}_{2} \mathrm{O} 6 \cdot 0, \mathrm{ZnCO}_{3} 1 \cdot 6, \mathrm{MnCO}_{3} 3 \cdot 5, \mathrm{CuCO}_{3}$ $0 \cdot 3, \mathrm{KIO}_{3} 0 \cdot 01, \mathrm{Na}_{2} \mathrm{SeO}_{3} .5 \mathrm{H}_{2} \mathrm{O} 0 \cdot 01, \mathrm{CrK}\left(\mathrm{SO}_{4}\right)_{2} .12 \mathrm{H}_{2} \mathrm{O} 0 \cdot 55$, sucrose 118.03 .

\section{Biochemical analyses}

Haemoglobin concentrations and packed cell volumes were determined in tail-blood samples of dams and pups according to the method of Richterich (1969). Livers, spleens, and carcasses were dry-ashed at $550^{\circ}$ for 24 h (Blue M Muffle Furnace; Scientific Products, McGaw Park, Illinois) and milk was wet-ashed using concentrated nitric acid-sulphuric acid $(4: 1, v / v)$. Pup tissues were pooled within each litter before ashing. Fe concentrations were determined by atomic absorption spectrophotometry (Jarell-Ash, Fisher Scientific Co., Pittsburgh, Pennsylvania).

\section{Statistical analyses}

In Expt 1, comparisons were made among the four groups by analysis of variance, followed by least significant difference and Duncan's multiple range tests. The probability level for significance was $P \leqslant 0.05$. In Expt 2 , the two groups were compared for all measurements using Student's $t$ test (Nie et al. 1975).

\section{RESULTS}

\section{Expt 1}

Dams. Initial body-weights, food consumption during gestation and lactation, and final body-weights of all treatment groups were similar (Table 2). Litters were born on day 21 or 22 of gestation and no differences among groups in litter size were observed.

There were no significant differences among dietary Fe treatments in maternal haemoglobin concentrations, packed cell volumes or liver and spleen dry weights at the end of the $20 \mathrm{~d}$ lactation period (Table 3). Spleen Fe concentration was lowest in the $75 \mathrm{mg} \mathrm{Fe} / \mathrm{kg}$ diet group. Liver Fe concentrations were significantly elevated as dietary Fe increased from 35 to $75 \mathrm{mg} / \mathrm{kg}$, and from 150 to $300 \mathrm{mg} / \mathrm{kg}$. Although milk Fe concentration appeared to be lowest in the $35 \mathrm{mg} \mathrm{Fe} / \mathrm{kg}$ diet group, this difference was not statistically significant.

Pups. Table 4 contains body-weights and total body Fe determinations from pups on days 1 and 20 . On day 1, pups born to dams given the $75 \mathrm{mg} \mathrm{Fe} / \mathrm{kg}$ diet were heavier than pups in the other groups. However, when day 1 body-weights were expressed on a dry-weight 
Table 2. Expt 1. Body-weights and food intakes of dams during pregnancy and lactation (Mean values with their standard errors for six to eight dams/group)

\begin{tabular}{|c|c|c|c|c|c|c|c|c|}
\hline \multirow[t]{2}{*}{ Dietary Fe $(\mathrm{mg} / \mathrm{kg})$. } & \multicolumn{2}{|c|}{35} & \multicolumn{2}{|c|}{75} & \multicolumn{2}{|c|}{150} & \multicolumn{2}{|c|}{300} \\
\hline & Mean & $\mathrm{SE}$ & Mean & $\mathrm{SE}$ & Mean & $\mathrm{SE}$ & Mean & $\mathrm{SE}$ \\
\hline \multicolumn{9}{|l|}{ Body-wt (g) } \\
\hline Day 1 of pregnancy & $212 \cdot 5$ & $2 \cdot 1$ & $218 \cdot 8$ & $4 \cdot 2$ & $205 \cdot 5$ & $3 \cdot 7$ & $211 \cdot 3$ & $3 \cdot 4$ \\
\hline Day 20 of lactation & $303 \cdot 6$ & $16 \cdot 5$ & $326 \cdot 3$ & $14 \cdot 8$ & $284 \cdot 7$ & $21 \cdot 2$ & $289 \cdot 6$ & 6.6 \\
\hline \multicolumn{9}{|l|}{ Food intake $(\mathrm{g})$} \\
\hline Pregnancy & 457 & 19 & 473 & 29 & 435 & 23 & 423 & 15 \\
\hline Lactation & 568 & 61 & 659 & 24 & 680 & 49 & 674 & 11 \\
\hline Litter size & 12 & 1 & 12 & 2 & 11 & 1 & 12 & 1 \\
\hline
\end{tabular}

Analysis of variance revealed no significant differences among treatments.

Table 3. Expt 1. Iron status of dams on day 20 of lactation

(Mean values with their standard errors for six to eight dams/group)

\begin{tabular}{|c|c|c|c|c|c|c|c|c|}
\hline \multirow[t]{2}{*}{ Dietary Fe $(\mathrm{mg} / \mathrm{kg}) \ldots$} & \multicolumn{2}{|c|}{35} & \multicolumn{2}{|c|}{75} & \multicolumn{2}{|c|}{ I 50} & \multicolumn{2}{|c|}{300} \\
\hline & Mean & SE & Mean & SE & Mean & $\mathrm{SE}$ & Mean & SE \\
\hline Haemoglobin $(\mathrm{g} / 100 \mathrm{ml})$ & $16 \cdot 4$ & 0.5 & $17 \cdot 3$ & $0 \cdot 2$ & $17 \cdot 4$ & $0 \cdot 6$ & $16 \cdot 6$ & 0.4 \\
\hline Packed cell volume & 0.50 & 0.01 & 0.52 & 0.01 & 0.54 & 0.02 & 0.49 & 0.01 \\
\hline Dry spleen wt (g) & $0 \cdot 184$ & $0 \cdot 023$ & 0.256 & 0.026 & $0 \cdot 161$ & 0.026 & $0 \cdot 197$ & 0.019 \\
\hline Spleen Fe $(\mu \mathrm{g} / \mathrm{g}$ dry wt $)$ & 2570 & $270^{\mathrm{a}, \mathrm{b}}$ & 1960 & $170^{\mathrm{b}}$ & 3020 & $320^{\mathrm{a}}$ & 3200 & $500^{\mathrm{a}}$ \\
\hline Dry liver wt (g) & $3 \cdot 73$ & $0 \cdot 235$ & $4 \cdot 31$ & 0.207 & 3.66 & 0.359 & 3.88 & 0.223 \\
\hline Liver Fe $(\mu \mathrm{g} / \mathrm{g}$ dry wt) & 246 & $9^{a}$ & 481 & $26^{\mathrm{b}}$ & 508 & $58^{\mathrm{b}}$ & 598 & $26^{\mathrm{c}}$ \\
\hline Milk Fe $(\mu \mathrm{g} / \mathrm{ml})$ & $12 \cdot 9$ & 0.5 & $14 \cdot 5$ & 0.9 & $14 \cdot 3$ & $0 \cdot 1$ & $14 \cdot 7$ & 0.7 \\
\hline
\end{tabular}

Mean values with unlike a,b,c, superscript letters were significantly different $(P<0.05)$.

Table 4. Expt 1. Body-weights and total body iron concentrations of pups on days 1 and 20 (Mean values with their standard errors for seven to eight litters/group)

\begin{tabular}{|c|c|c|c|c|c|c|c|c|}
\hline \multirow[t]{2}{*}{ Dietary $\mathrm{Fe}(\mathrm{mg} / \mathrm{kg}) \ldots$} & \multicolumn{2}{|c|}{35} & \multicolumn{2}{|c|}{75} & \multicolumn{2}{|c|}{150} & \multicolumn{2}{|c|}{300} \\
\hline & Mean & SE & Mean & SE & Mean & SE & Mean & SE \\
\hline \multicolumn{9}{|l|}{ Day 1} \\
\hline Body-wt $(\mathrm{g})$ & $5 \cdot 8$ & $0 \cdot 1^{\mathbf{a}}$ & $6 \cdot 7$ & $0 \cdot 2^{\mathrm{b}}$ & $5 \cdot 7$ & $0 \cdot 2^{\mathrm{a}}$ & $5 \cdot 9$ & $0 \cdot 3^{\mathrm{a}}$ \\
\hline Dry body-wt (g) & 0.862 & $0 \cdot 021^{\mathrm{a}}$ & 1.004 & $0.041^{\mathrm{D}}$ & 0.946 & $0.038^{a \cdot b}$ & 0.988 & $0 \cdot 043^{b}$ \\
\hline Total body $\mathrm{Fe}(\mu \mathrm{g} / \mathrm{g}$ dry wt $)$ & 315 & 9 & 335 & 18 & 327 & 9 & 328 & 15 \\
\hline \multicolumn{9}{|l|}{ Day 20} \\
\hline Body-wt (g) & 46.5 & $2 \cdot 9$ & $50 \cdot 6$ & $2 \cdot 6$ & $51 \cdot 7$ & $1 \cdot 5$ & $50 \cdot 3$ & $1 \cdot 3$ \\
\hline Dry body-wt (g) & $16 \cdot 5$ & $1 \cdot 63^{a}$ & $21 \cdot 1$ & $2 \cdot 13^{\mathbf{a}, \mathbf{b}}$ & $20 \cdot 1$ & $1 \cdot 46^{\mathrm{a} . \mathrm{b}}$ & $22 \cdot 4$ & $1 \cdot 72^{b}$ \\
\hline Total body $\mathrm{Fe}(\mu \mathrm{g} / \mathrm{g}$ dry wt $)$ & 39 & $2^{u}$ & 52 & $5^{b}$ & 71 & $5^{b}$ & 65 & $10^{\mathrm{b}}$ \\
\hline
\end{tabular}

Mean values with unlike a,b,c superscript letters were significantly different $(P<0 \cdot 05)$. 
Table 5. Expt 1. Iron status of pups on day 20

(Mean values with their standard errors for seven to eight litters/group)

\begin{tabular}{|c|c|c|c|c|c|c|c|c|}
\hline \multirow[t]{2}{*}{ Dietary $\mathrm{Fe}(\mathrm{mg} / \mathrm{kg}) \ldots$} & \multicolumn{2}{|c|}{35} & \multicolumn{2}{|c|}{75} & \multicolumn{2}{|c|}{150} & \multicolumn{2}{|c|}{300} \\
\hline & Mean & $\mathrm{SE}$ & Mean & SE & Mean & SE & Mean & SE \\
\hline Haemoglobin $(\mathrm{g} / 100 \mathrm{ml})$ & $8 \cdot 6$ & $0 \cdot 4^{a}$ & $9 \cdot 0$ & $0 \cdot 4^{\mathrm{a}, \mathrm{b}}$ & $9 \cdot 6$ & $0 \cdot 5^{\mathrm{a}, \mathrm{b}}$ & $10 \cdot 1$ & $0 \cdot 4^{b}$ \\
\hline Packed cell volume & 0.32 & $0 \cdot 02^{\mathrm{a}}$ & 0.33 & $0 \cdot 01^{\mathrm{a}, \mathrm{b}}$ & $0 \cdot 35$ & $0 \cdot 01^{\mathrm{a}, \mathrm{b}}$ & $0 \cdot 37$ & $0.01^{\mathrm{b}}$ \\
\hline Dry spleen wt (g) & 0.038 & 0.002 & 0.049 & 0.004 & 0.052 & 0.003 & 0.047 & 0.006 \\
\hline Spleen $F e(\mu g / g$ dry wt) & 178 & $27^{\mathrm{a}}$ & 219 & $14^{\mathrm{b}}$ & 221 & $12^{\mathrm{b}}$ & 346 & $23^{\mathrm{c}}$ \\
\hline Dry liver wt $(\mathrm{g})$ & 0.435 & 0.029 & 0.515 & 0.036 & 0.522 & 0.031 & 0.494 & 0.036 \\
\hline Liver Fe ( $\mu \mathrm{g} / \mathrm{g}$ dry wt) & 76 & $8^{\mathrm{a}}$ & 98 & $6^{\mathrm{a}}$ & 99 & $7^{\mathrm{a}}$ & 139 & $14^{\mathrm{b}}$ \\
\hline
\end{tabular}

Mean values with unlike a,b,c superscript letters were significantly different $(P<0 \cdot 05)$.

Table 6. Expt 2. Body-weights and iron status of dams on day 20 of lactation

(Mean values with their standard errors for ten dams/group)

\begin{tabular}{clccccc}
\hline $\begin{array}{c}\text { Dietary } \\
\mathrm{Fe} \\
(\mathrm{mg} / \mathrm{kg})\end{array}$ & $\begin{array}{c}\text { Initial } \\
\text { body-wt } \\
(\mathrm{g})\end{array}$ & $\begin{array}{c}\text { Final } \\
\text { body-wt } \\
(\mathrm{g})\end{array}$ & $\begin{array}{c}\text { Haemoglobin } \\
(\mathrm{g} / 100 \mathrm{ml})\end{array}$ & $\begin{array}{c}\text { Liver Fe } \\
(\mu \mathrm{g} / \mathrm{g} \text { dry wt })\end{array}$ & $\begin{array}{c}\text { Spleen Fe } \\
(\mu \mathrm{g} / \mathrm{g} \mathrm{dry} \mathrm{wt})\end{array}$ \\
\hline \multirow{2}{*}{250} & Mean & $205 \cdot 7$ & $261 \cdot 5$ & $14 \cdot 3$ & 548 & 1690 \\
& SE & $2 \cdot 7$ & $4 \cdot 3$ & $0 \cdot 2$ & 58 & 80 \\
300 & Mean & $204 \cdot 8$ & $257 \cdot 8$ & $14 \cdot 7$ & 568 & 1900 \\
& $\mathrm{SE}$ & $2 \cdot 2$ & $3 \cdot 8$ & $0 \cdot 2$ & 58 & 80 \\
\hline
\end{tabular}

Statistical analysis using Student's $t$ tests revealed no significant differences between groups.

basis, this difference was not significant. Total body Fe concentrations on day 1 were similar among treatments.

Although mean body-weights of pups on day 20 were lowest in the $35 \mathrm{mg} \mathrm{Fe} / \mathrm{kg}$ diet group, the only statistically significant difference was between the 35 and $300 \mathrm{mg} \mathrm{Fe} / \mathrm{kg}$ diet treatments when body-weights were expressed on a dry-weight basis. Total body $\mathrm{Fe}$ concentrations on day 20 were significantly lower in the $35 \mathrm{mg} \mathrm{Fe} / \mathrm{kg}$ diet group than in other groups.

Measurements of $\mathrm{Fe}$ status in pups on day 20 are presented in Table 5. Pup haemoglobin concentrations and packed cell volumes increased with increasing Fe in the dams' diet. This increase was significant between the 35 and $300 \mathrm{mg} \mathrm{Fe} / \mathrm{kg}$ diet treatments. Dry spleen and liver weights were not significantly different among groups. Spleen and liver Fe concentrations were significantly higher in the $300 \mathrm{mg} \mathrm{Fe} / \mathrm{kg}$ group than in the other groups given less $\mathrm{Fe}$.

\section{Expt 2}

Dams and pups. Body-weights and Fe status of dams on day 20 of lactation are summarized in Table 6. Dietary Fe level had no significant effect on final body-weight, haemoglobin concentration, or liver and spleen Fe concentration. Also, food intake, total liver and spleen $\mathrm{Fe}$, and packed cell volume (values not shown) were similar between the two groups. Pups in both groups had similar body-weights, haemoglobin concentrations and liver and spleen $\mathrm{Fe}$ concentrations on day 20 of lactation (Table 7). 
Table 7. Expt 2. Body-weights and iron status of pups on day 20 of lactation

(Mean values with their standard errors for ten litters/group)

\begin{tabular}{ccccccc}
\hline \hline $\begin{array}{c}\text { Dietary } \\
\text { Fe } \\
(\mathrm{mg} / \mathrm{kg})\end{array}$ & $\begin{array}{c}\text { Body-wt } \\
(\mathrm{g})\end{array}$ & $\begin{array}{c}\text { Haemoglobin } \\
(\mathrm{g} / 100 \mathrm{ml})\end{array}$ & $\begin{array}{c}\text { Total body Fe } \\
(\mu \mathrm{g} / \mathrm{g} \text { dry } \mathrm{wt})\end{array}$ & $\begin{array}{c}\text { Spleen Fe } \\
(\mu \mathrm{g} / \mathrm{g} \text { dry wt })\end{array}$ & $\begin{array}{c}\text { Liver Fe } \\
(\mu \mathrm{g} / \mathrm{g} \text { dry wt })\end{array}$ \\
\hline \multirow{2}{*}{250} & Mean & $49 \cdot 3$ & $9 \cdot 3$ & 120 & 379 & 499 \\
& SE & $1 \cdot 3$ & $0 \cdot 3$ & 10 & 12 & 63 \\
300 & Mean & $45 \cdot 2$ & $9 \cdot 0$ & 93 & 398 & 466 \\
& SE & 1.9 & $0 \cdot 2$ & 10 & 19 & 44 \\
\hline
\end{tabular}

Statistical analysis using Student's $t$ tests revealed no significant differences between groups.

\section{DISCUSSION}

A dietary $\mathrm{Fe}$ concentration of $35 \mathrm{mg} / \mathrm{kg}$ during gestation and lactation maintained maximum weight gain, food intake, liver and spleen weight, haemoglobin concentration, and packed cell volume in the growing maternal rat. This extends the results reported in the literature from studies designed to determine an Fe requirement for gestation in the rat. Ahlstrom \& Jantti (1969) found that $28 \mathrm{mg} \mathrm{Fe} / \mathrm{kg}$ diet during pregnancy maintained maximum haemoglobin concentration and packed cell volume. Lin \& Kirksey (1976) reported that $10 \mathrm{mg} \mathrm{Fe} / \mathrm{kg}$ diet resulted in maximal body-weights in growing, pregnant rats, but that between 10 and $50 \mathrm{mg} \mathrm{Fe} / \mathrm{kg}$ diet was needed for growing rats to attain maximal haemoglobin concentrations.

To assess the drain on maternal Fe stores during gestation and lactation, Fe concentrations in dam liver and spleen were measured. Fe concentrations in these organs often had large variances associated with them, which made the results difficult to interpret. Despite these variances, in both experiments, dams in the 150,250 and $300 \mathrm{mg} \mathrm{Fe} / \mathrm{kg}$ diet groups had the highest liver and spleen Fe concentrations. The lower values for dams in the 35 and $75 \mathrm{mg} \mathrm{Fe} / \mathrm{kg}$ groups indicated that at some time during gestation and lactation, liver and spleen $\mathrm{Fe}$ was mobilized to meet their own $\mathrm{Fe}$ needs or the Fe requirements of their pups or both. Thus, the dietary Fe concentration that maintained weight gain and haemoglobin concentration $(35 \mathrm{mg} \mathrm{Fe} / \mathrm{kg}$ ) was lower than the level necessary to maximize liver and spleen $\mathrm{Fe}$ concentrations in dams at the end of lactation.

Maternal dietary Fe concentration had a slight effect on growth of offspring. Dry body-weights of pups on days 1 and 20 tended to be lower in the $35 \mathrm{mg} \mathrm{Fe} / \mathrm{kg}$ diet group. This suggested that a dietary Fe level of $35 \mathrm{mg} / \mathrm{kg}$ may not have provided for optimal growth in pups during gestation and lactation.

The minimum dietary $\mathrm{Fe}$ level necessary to maximize pup stores at the end of lactation was considered important because increased foetal resorptions have been reported with the feeding of excessive dietary $\mathrm{Fe}$ (Lin \& Kirksey, 1976). In Expt 1, it was found that between 150 and $300 \mathrm{mg} \mathrm{Fe} / \mathrm{kg}$ diet maximized Fe stores in 20-d-old pups. By comparing dietary Fe levels of 250 and $300 \mathrm{mg} / \mathrm{kg}$ in Expt 2, it appeared that $250 \mathrm{mg} \mathrm{Fe} / \mathrm{kg}$ diet maximized pup Fe stores. In Expts 1 and 2, the source of the increased liver Fe in pups nursed by dams given a 250 or $300 \mathrm{mg} \mathrm{Fe} / \mathrm{kg}$ diet is not certain. Linder et al. (1972) reported that the $\mathrm{Fe}$ deposited in foetal livers before birth was greater with more Fe in the maternal diet. In Expt 1, liver $\mathrm{Fe}$ concentration at birth was not measured. Since total body $\mathrm{Fe}$ concentrations on day 1 were similar in all groups, it cannot be determined whether pup liver Fe concentrations in the $300 \mathrm{mg} \mathrm{Fe} / \mathrm{kg}$ diet group were high enough at birth to account for the significant 
elevation in liver Fe concentration observed in this group on day 20. It is also possible that milk Fe concentrations varied with dietary Fe levels. Keen et al. (1981) have shown that the Fe concentration in rat milk decreases over the course of lactation. Also, it has been reported that the $\mathrm{Fe}$ concentration measured in rat milk at a given point in lactation varies with the amount of $\mathrm{Fe}$ in the maternal diet (Anaokar \& Garry, 1981). Although $\mathrm{Fe}$ concentrations measured in milk samples collected on day 20 were similar among groups, there may have been differences among groups earlier in lactation, resulting in increased Fe being transferred to pups in the $300 \mathrm{mg} \mathrm{Fe} / \mathrm{kg}$ diet group.

In conclusion, a dietary $\mathrm{Fe}$ concentration between 75 and $250 \mathrm{mg} / \mathrm{kg}$ provided for optimal $\mathrm{Fe}$ status of dams at the end of lactation. However, a maternal dietary $\mathrm{Fe}$ concentration between 150 and $250 \mathrm{mg} / \mathrm{kg}$ was necessary to maximize Fe stores in 20-d-old pups. It is hoped that the results of these experiments will be helpful to researchers in formulating mineral mixtures for use in experiments involving reproduction.

The authors would like to thank Ina Silvergleid for her technical assistance in Expt 2. This research was supported in part by a grant, no. 60-337, from the University of Illinois Agriculture Experiment Station and in part by a grant from the National Institutes of Health HD, no. 15515 .

\section{REFERENCES}

Ahlstrom, A. \& Jantti, M. (1969). Ann. Acad. Sci. Fenn. A, Biologica 152, 1.

Anaokar, S. G. \& Garry, P. J. (1981). Am. J. clin. Nutr. 34, 1505.

Cerklewski, F. L. (1979). J. Nutr. 109, 1529.

Keen, C. L., Lonnerdal, B., Clegg, M. \& Hurley, L. S. (1981). J. Nutr. 111, 226.

Lin, W. J. \& Kirksey, A. (1976). J. Nutr. 106, 543.

Linder, M. C., Moor, J. R., Scott, L. E. \& Munro, H. N. (1972). Biochem. J. 129, 455.

McCall, M. G., Newman, G. E., O'Brien, J. R. P., Valberg, L. S. \& Witts, L. J. (1962). Br. J. Nutr. $16,297$.

National Research Council (1978). Nutrient Requirements of Laboratory Animals no. 10, 3rd ed. Washington, DC: National Academy of Sciences.

Nie, N. H., Hull, C. H., Jenkins, J. G., Steinbrennar, K. \& Bent, D. H. (1975). SPSS: Statistical Package for the Social Sciences, 2nd ed. New York: McGraw-Hill.

Richterich, R. (1969). Clinical Chemistry. Basel: Basler Purck und Verlagsanstalt. 